\title{
荷重伝達型十字す久内溶接継手・ルー十破壊の 波労強度評価方法の提案
}

\section{森＼cjkstart猛* ·貝沼重信**}

\begin{abstract}
荷重伝達型十字すみ肉溶接継手がルート破壊する場合の適切な疲労強度評価方法を明 らかとすることを目的として, 二等辺三角形, 主板側に長い不等脚, 中板側に長い不等 脚, 凹形および凸形のすみ肉溶接を有する試験体の疲労試験を行なうとともに, 種々の 形状・寸法の十字すみ肉溶接継手を対象とした疲労亀裂進展解析を行なった. それらの 結果に基づき, 疲労強度に対する板厚, 溶接サイズ, 溶込み深さ, 溶接形状の影響につ いて検討し, 疲労強度を定量的に評価するためののど厚の算定方法を提案した.
\end{abstract}

Key Words : cruciform joint, fillet weld, fatigue strength, root failure, weld shape

1.はじめに

近年，鋼道路橋においても疲労亀裂の発生事例が数多 く報告されている1)。その一つに荷重伝達型十字すみ肉溶 接継手と夕なされる溶接部のルートから生じる疲労亀裂 がある。このような溶接部の疲労強度を精度よく評価す るための方法を明確とすることは，鋼橋を疲労に対して 安全に使用する上で重要である. Frankらは有限要素解析 結果に基づきルートから発生する疲労亀裂の応力拡大係 数を計算するための経験式を示すとともに，その経験式 を用いて疲労亀裂進展解析を行ない, 疲労強度を評価す るための応力範囲算定式を提案している ${ }^{2)}$. また, 舘石ら は，Frankらと同様の進展解析を行なった結果に基づき， 中板側の溶接脚長に溶接長を乗じたものを断面積として 応力範囲を計算することを提案している ${ }^{3)}$. ただし, これ らは二等辺三角形のすみ溶接を有する継手に対して検討 されたものである．溶接姿勢や溶接条件によっては，す み肉溶接が不等脚，凹形あるいは凸形となる場合も少な くない.

著者らは，二等辺三角形，不等脚，凹形および凸形の すみ肉溶接を有する荷重伝達型十字継手を対象として, ルートから発生する疲労亀裂の応力拡大係数の解析およ びその結果に基づいた疲労亀裂進展解析を行なうことに より, 疲労強度に対する板厚, 溶込み深さ, 溶接サイズ, 溶接形状の影響について検討した ${ }^{4)}$. その結果に基づき， のど厚を（溶接サイズ+溶込み深さ）/ $\sqrt{2}$ としてのど断 面応力を計算すること, 許容応力範囲を日本鋼構造協 会・疲労設計指針(案) ${ }^{5)}$ の H等級とすることを提案した. また，このような応力算定方法を用いれば，溶接形状が 不等脚，凹，凸となっても危険側の評価とはならないこ

* 正会員 工博 法政大学助教授 工学部土木工学科 （T184 東京都小金井市梶野町 3-7-2）

**正会員 工修 名古屋大学助手 工学部土木工学科 (研究当時 法政大学大学院)
とを示した.この検討結果は，1993年6月に改定出版され た『鋼構造物の疲労設計指針・同解説』 ${ }^{6}$ ( 以後, JSSC指 針と呼ぶ) に反映されている.

本研究では，溶接形状が二等辺三角形，主板側に長い 三角形，中板側に長い三角形，凹形および凸形の 5 種類 の荷重伝達型十字すみ肉溶接継手の疲労試験を行ない, 前報 ${ }^{4)}$ での解析結果の妥当性を確か力る. さらに, 疲労亀 裂進展解析の対象を堌やし, 疲労強度に対する主板の厚 さ, 溶接サイズ, 溶接の溶込夕深さ, 溶接形状の影響に ついて詳細に検討することにより，荷重伝達型十字すみ 肉溶接継手がルート破壊する場合の疲労強度を精度よく 評価するためのすみ肉溶接のど厚の算定方法を提案する.

\section{2、試験方法}

供試鋼材は板厚 $16 \mathrm{~mm}$ のJIS SS400であり，その降伏点は $315 \mathrm{MPa}$ ，引張強度は451MPa，伸びは32\%である．試験体は， 図一1に示すように，すみ肉溶接が二等辺三角形，主板側 に脚長が長い不等脚，中板側に脚長が長い不等脚，回形 および凸形の計 5 種類の荷重伝達型十字すみ肉溶接継手 である．以後，これらの試験体を $\triangle$ 試験体， 試験体， $\Delta$ 試験体, 凹試験体および凸試験体と呼ぶ。溶接サイズ の目標值は，いづれも $7 \mathrm{~mm}$ である.すみ肉溶接はフラック スコアタイプのワイヤ $(1.2 \phi)$ を用いた自動 $\mathrm{CO}_{2}$ 溶接法に より下向きで行なった. 各試験体の溶接条件を表ー1に示 す.

疲労試験は, 動的能力 $\pm 100 \mathrm{kN}$ の電気油圧サーボ式材料 試験機を用い, 溶接ルート部の圧縮残留応力の影響を受 けないように，すなわち未溶着部の閉口が生じないよう に上限荷重を $90 \mathrm{kN}$ るいは $100 \mathrm{kN}$ とた片振り引張荷重 下で行なった ${ }^{7), 8)}$. 荷重波形は正弦波, 繰返し速度は 4 〜20Hzである. 未溶着部の開閉口挙動は，未溶着部先端 近傍にゲージ長 $0.5 \mathrm{~mm}$ のひずタゲージを貼付し(図ー2参 照），荷重とひずみ值の関倸を測定することにより観察 した. 


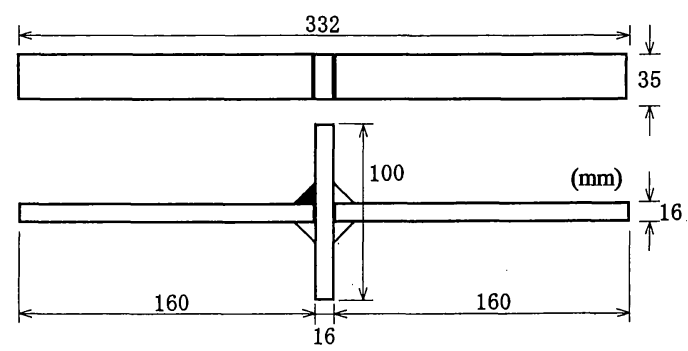

溶接形状詳細

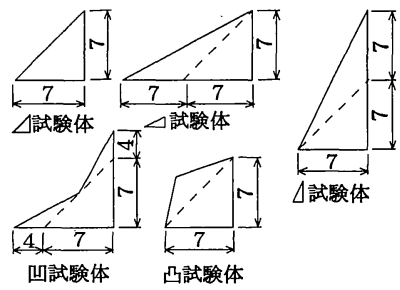

図-1 試験体の形状・法

\begin{tabular}{|c|c|c|c|c|c|}
\hline \multirow[b]{2}{*}{ 試験体 } & 電流 & 電圧 & 速度 & \multicolumn{2}{|c|}{ ウ1-ピ゙仿グ条件 } \\
\hline & (A) & (V) & $(\mathrm{cm} / \mathrm{min})$ & 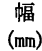 & $\begin{array}{c}\text { 速度 } \\
\text { (回/min) }\end{array}$ \\
\hline$\Delta$ & 280 & 35.5 & 40 & \multicolumn{2}{|r|}{-} \\
\hline$\Delta$ & 280 & 33 & 70 & & - \\
\hline \multirow[b]{2}{*}{$\Delta$} & $\frac{280}{280}$ & $\frac{35.5}{33}$ & 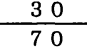 & \multicolumn{2}{|r|}{-} \\
\hline & 280 & 35.5 & 30 & 7 & 60 \\
\hline \multirow{3}{*}{ 凹 } & 280 & 33 & 70 & \multicolumn{2}{|r|}{-} \\
\hline & 280 & 35.5 & 30 & 7 & 60 \\
\hline & 280 & 35.5 & 65 & 4 & 100 \\
\hline \multirow{2}{*}{ 凸 } & 280 & 33 & 70 & \multirow{2}{*}{\multicolumn{2}{|c|}{$\begin{array}{l}- \\
-\end{array}$}} \\
\hline & 280 & 35.5 & 30 & & \\
\hline
\end{tabular}

積層方法
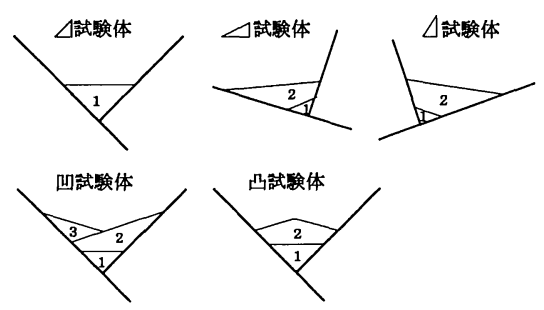

\section{3. 試験結果}

各試験体の疲労破壊の様子の例を写真一1に示す.いず れの場合も疲労亀裂は未溶着部先端より生じ, 未溶着部 とほぼ同一線上に進展している。なお，破断線がほぼ45 度傾いている部分は, 最終的な静的破壊が生じた部分で ある。

図ー2に荷重と未溶着部先端近傍におけるひずみの関係 の例を示す，これらの例では, 凸試験体と凹試験体にお いて荷重範囲が最も大きい試験，すなわち未溶着部の閉 口が最も生じやすい試験で求めた関係を示している。凸 試験体では，最小荷重以下で未溶着部先端の開閉口が生
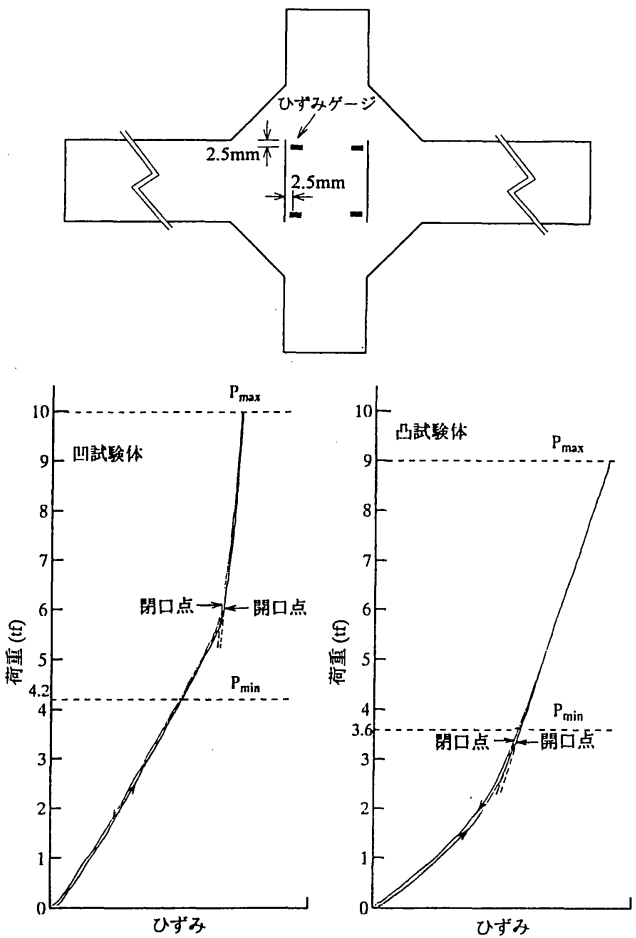

図-2 未溶着部の開閉口挙動の測定結果

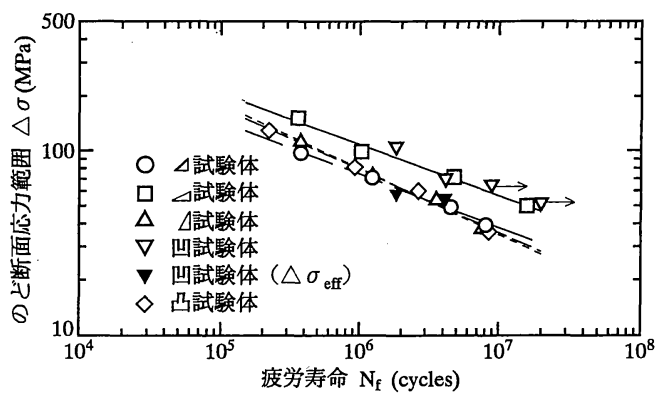

図一 3 疲労試験結果

じており，圧縮残留応力の影響は受けないと言える。こ のことは， $\Delta ， \triangle 、 \Delta$ 試験体においても同様であった. 一 方, 凹試験体では, 溶接量が他の試験体に比べて多いた めか,，未溶着部先端の開閉口点が高く, 試験荷重範囲内 にある.

各試験体の疲労試験結果を図ー3に示す，図の縦軸はの ど断面応力範囲 $\Delta \sigma$ であり，のど断面積をJSSC指針にした がい（溶接サイズ+溶込み深さ） $/ \sqrt{2} \times($ 板幅）として 計算した。 なお， 凹試験体については，未溶着部先端が 開口している間の応力の変動幅 $\left(\Delta \sigma_{\text {eff }}\right)$ で整理した結果 も示している. 図中の直線群は最小自乗法を用いて求め た各試験体の疲労寿命に対する応力範囲の回帰直線で ある.ただし，凹試験体については，破断データが 


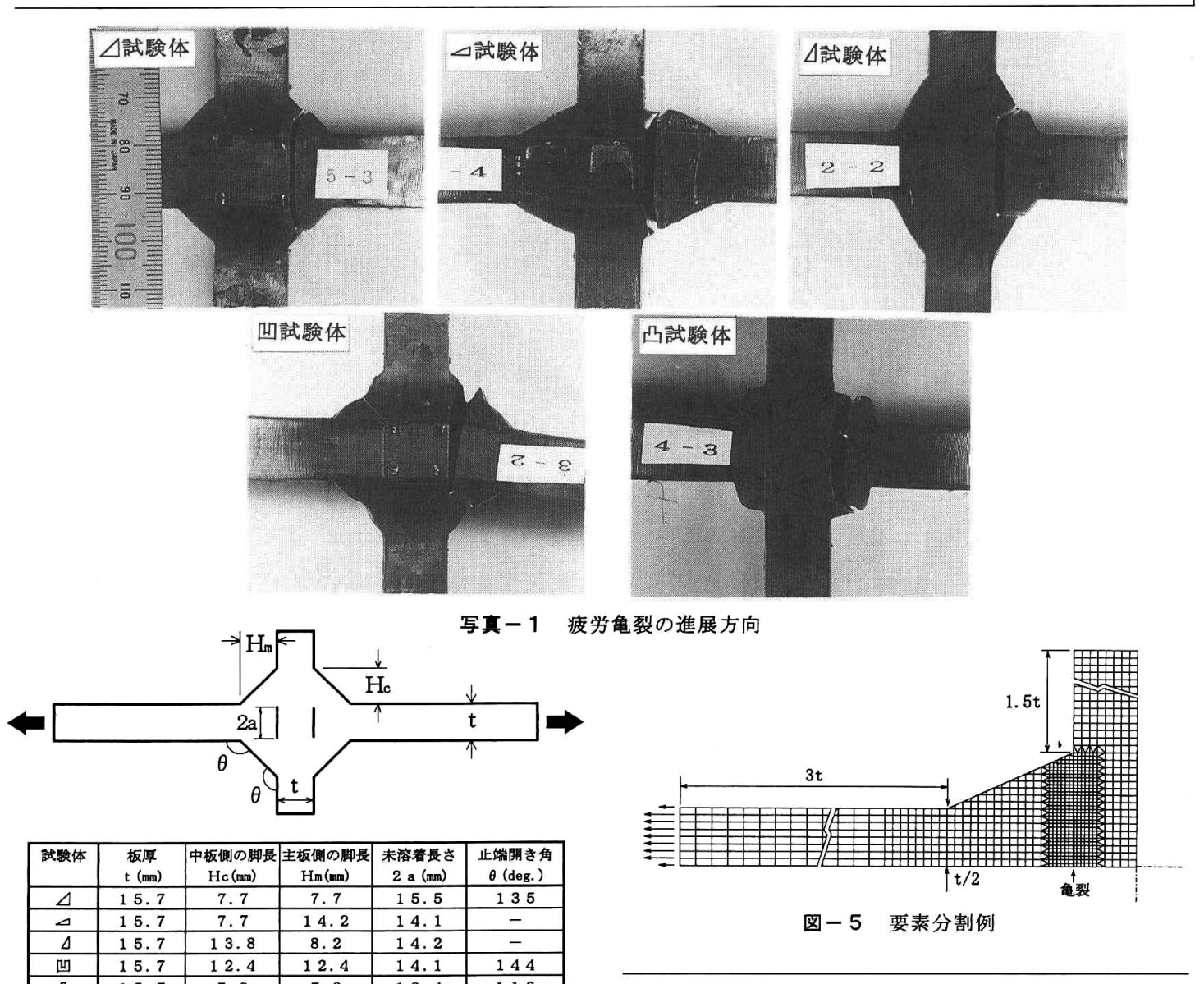

図ー4 疲労試験体のモデル化

2つしかないため, 回帰直線は示していない.

回帰直線（四試験体については，2つの破断データの 内挿）より求めた $2 \times 10^{6}$ 回疲労強度は， $\Delta, \Delta, \Delta$, 几， 凸試験体で，それぞれ $61 ， 89 ， 63 ， 100 ， 63 \mathrm{MPa}$ である。 このように，溶接形状を中板側に不等脚あるいは凸形と しても，同じ溶接サイズの二等辺三角形のすみ肉溶接を 有する継手の疲労強度と同程度となっている. 一方, ○ 試験体の度労強度は， 試験体のおよそ1.45倍となってい る. 凹試験体の疲労強度も $\triangle$ 試験体に比べてかなり高い が, これは前述のように未溶着部先端の閉口が生じたた めと考えられる. $\Delta \sigma_{\text {off }}$ で整理した凹試験体の $2 \times 10^{6}$ 回疲 労強度は 59MPaである.

\section{4. 各試験体の疲労亀裂進展解析}

前章での試験体を対象として疲労亀裂進展解析を行な い, のど断面応力範囲 $\Delta \sigma$ と疲労寿命 $\mathrm{N}_{\mathrm{f}}$ の関係を求める. のど断面応力籁囲の算定方法は前章で示した通りである. 疲労亀裂進展解析は, 各亀裂長さに対する応力拡大係 数範囲 $\Delta \mathrm{K}$ を疲労亀裂進展速度 $\mathrm{da} / \mathrm{dN}$ との関係に

代入し，それを初期亀裂から限界亀裂まで繰返すことに より行なう。ここでは, 未溶着部を初期亀裂とみなし, その長さは未溶着長さの測定結果に基づき設定した. 限 界亀裂長さは, 破面の観察結果に基づき, $0.8 \times$ 脚長 (中板 側) +板厚 $/ 2$ とした．なお，脚長に乗じる係数を $0.6 \sim 0.9$ まで変化させても, 計算される寿命の違いは数\%以内で あった. 疲労庽裂の進展方向は, 前述の実験結果に基づ き, 引張荷重方向に対して垂直とした. da/dNと $\Delta \mathrm{K}$ の関 倸としてはJSSC指針 ${ }^{6)}$ に示されている平均設計曲線を用い た.

応力拡大係数は, 試験体の形状 - 寸法の測定結果に基 づき各試験体を図ー4に示すようにモデル化し，2 次元平 面ひずみ条件下で有限要素解析を行ない，その結果にエ ネルギー法を適用することにより算出した ${ }^{4)}$. 図一5に要 素分割例を示す，亀裂が進展する位置での要素の大きさ は主板厚の $1 / 30$ 程度以下とした ${ }^{4)}$.

図一6(a)，(b)に進展解析より求めた $\Delta \sigma-\mathrm{N}$ 関係を試 験結果とともに示す，凹試験体を除いた各試験体に対す る解析結果は試験結果とよく一致している.また, 凹試 験体についても， $\Delta \sigma_{\text {eff }}$ で整理すれば, 解析結果は実験 結果とほぼ一致している.したがって,ここで用いた条 件で疲労亀裂進展解析を行なうことにより, 種々の溶 


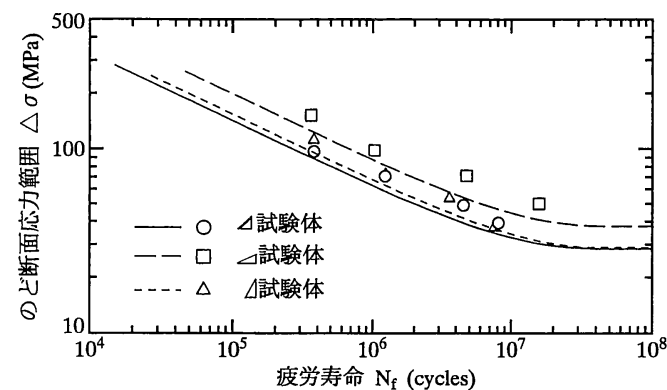

(a) $\Delta, \Delta, \Delta$ 試験体

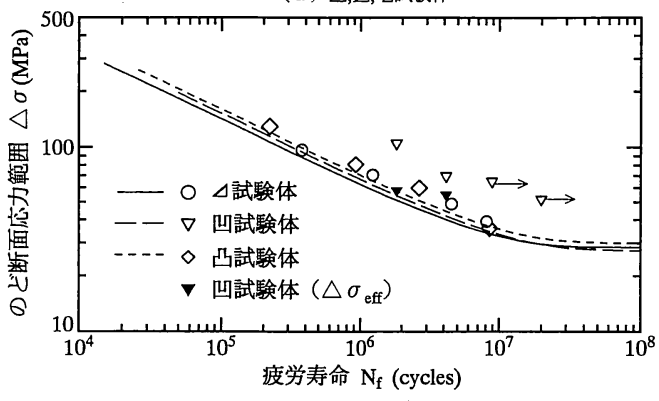

(b) $\Delta$,凹,凸試験体

図-6 疲労亀裂進展解析結果と試験結果の比較

\begin{tabular}{|c|c|c|c|c|}
\hline モデル番号 & 溶接形状 & $\begin{array}{l}\text { 板厚 } \\
\mathrm{t}(\mathrm{mm})\end{array}$ & $\begin{array}{c}\text { 溶接サイス/板厚 } \\
\mathrm{s} / \mathrm{t}\end{array}$ & $\begin{array}{c}\text { 脚長比, 此端開き角 } \\
\mathrm{Hm} / \mathrm{s} \text { or } \mathrm{Hc} / \mathrm{s}, \theta \text { (deg.) }\end{array}$ \\
\hline $1 \sim 23$ & $\Delta$ & $5 \sim 75$ & $0.2 \sim 1.2$ & - \\
\hline $24 \sim 87$ & $\Delta$ & $5 \sim 75$ & $0.2 \sim 1.2$ & $1.05 \sim 2.0^{* 1}$ \\
\hline $88 \sim 95$ & $\Delta$ & 25,36 & $0.3 \sim 0.8$ & $\left.1.3 \sim 2.0^{*}\right)$ \\
\hline 96,97 & 凹 & 36 & $21 / 36$ & $\left.145^{\circ}, 155^{\circ} * *\right)$ \\
\hline $98 \sim 100$ & 凸 & 36 & $21 / 36$ & $\left.101^{\circ}, 111^{\circ}, 123^{\circ} * *\right)$ \\
\hline
\end{tabular}

*) 脚長比 $(\mathrm{Hm} / \mathrm{s}$ あるいは $\mathrm{Hc} / \mathrm{s}), * *)$ 止端開き角
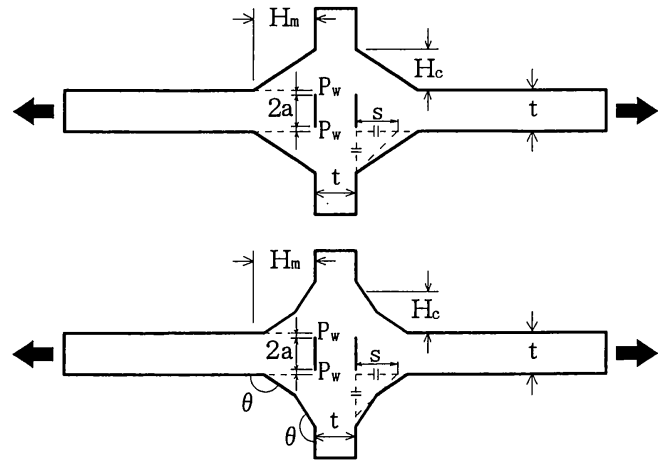

接形状を有する荷重伝達型十字すタ肉溶接継手がルート 破壊する場合の疲労寿命を精度良く予測できると言える.

\section{5. 疲労強度に及ぼす諸因子の影響}

本章では，疲労強度に対する板厚，溶接サイズ，溶込 み深さ, 溶接形状（不等脚，凹形および凸形）の影響に ついて疲労亀裂進展解析を行なうことにより検討する. 解析対象は，表一2に示す100のモデルである．これらの モデルでは, 溶接形状, 板厚 $t$, 溶接サイズ $s$, 脚長比

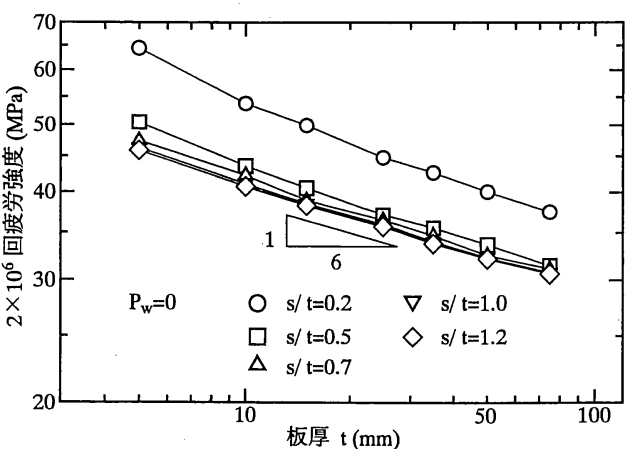

(a) パラメータ：溶接サイズ(溶接形状 $\Delta$ )

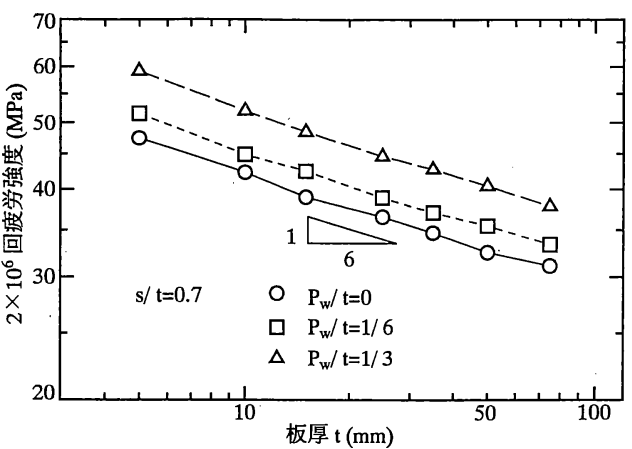

(b) パラメータ: 溶接サイズ (溶接形状 $\Delta$ )

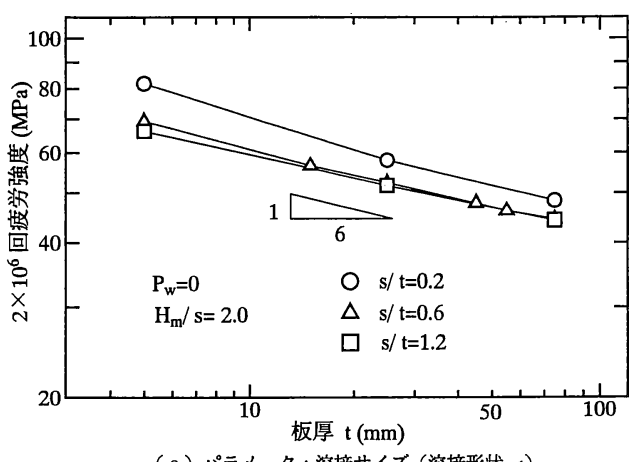

(c) パラメータ:溶接サイズ（溶接形状 $\Delta ）$

図ー7 疲労強度に及ぼす板厚の影響

$\mathrm{Hm} / \mathrm{s}, \mathrm{Hc} / \mathrm{s}$ ，止端の開き角 $\theta$ をパラメータとしている.さ らに, 各モデルについて, 溶込み深さ $\mathrm{Pw}$ 板厚 $\mathrm{t}$ の, 1/6, 1/3とした計300の条件で疲労亀裂進展解析を行 なっている. 応力拡大係数の算出方法および初期亀裂長 さと限界亀裂長さの設定方法は前章と同じである.ただ し, $\mathrm{da} / \mathrm{dN}-\Delta \mathrm{K}$ 関係はJSSC指針の最安全設計曲線とした.

\section{(1) 板厚の影響}

図一7(a)〜 (c) に疲労亀裂進展解析より求めた $2 \times 10^{6}$ 回 疲労強度と板厚の関係を示す. 図 (a)では二等辺三角形の すみ肉溶接を有する継手を対象とし, 溶込み深さを0, 溶接サイズを板厚の $0.2 \sim 1.2$ まで変化させた場合の結果 を示している。いずれの溶接サイズのモデルにお 


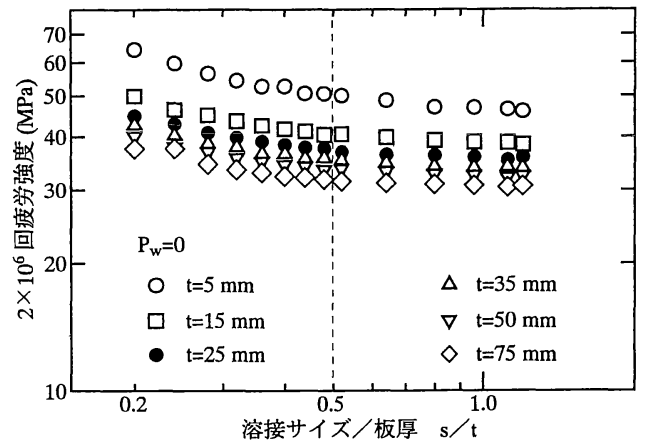

(a) パラメータ: 板厚 (溶接形状 $\Delta$ )

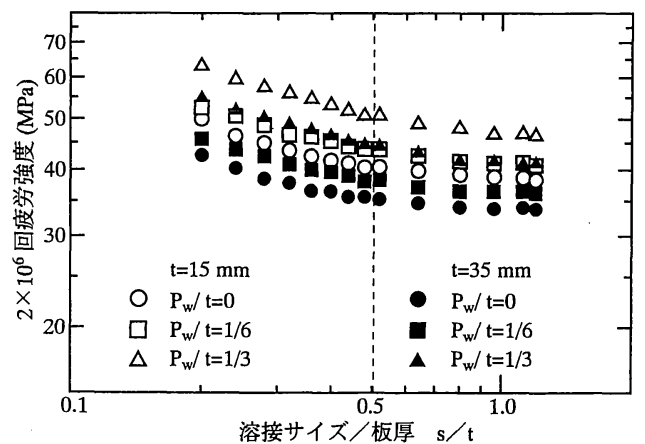

（b）パラメータ: 溶込み（溶接形状 $\Delta$ )

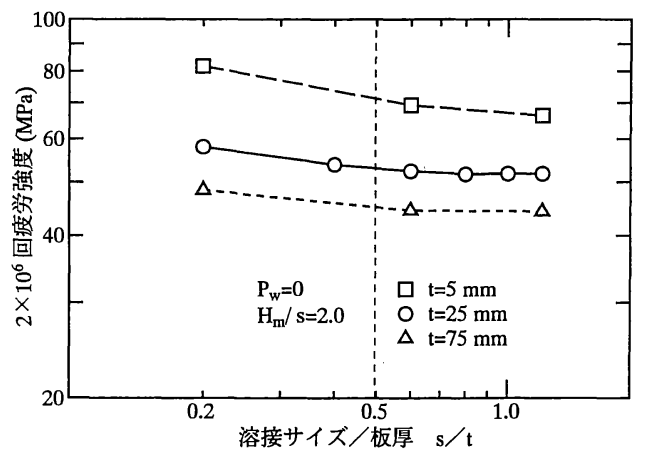

(c) パラメータ: 板厚 (溶接形状 $\Delta$ )

図ー8 疲労強度に及ぼす溶接サイズの影響

いても，疲労強度は板厚のほぼ $1 / 6$ 乗に反比例して低下 している，また，図(b)に示寸ように，この傾向は溶接の 溶込みがある場合においても同じである．図(c)恃不等脚 なすみ肉溶接を有する継手 $(\mathrm{Hm} / \mathrm{s}=2.0)$ での $2 \times 10^{6}$ 回疲労 強度と板厚の関係を示したものである.このような継手 においても, 疲労強度は板厚のほぼ1／6乗に反比例して 低下している．以上のように疲労強度が板厚の $1 / 6$ 乗に 反比例して低下寸る傾向は, 他の溶接形状, 溶込みの場 合にも同じであった.

このように，主板が厚くなるにしたがって疲労強度が 低下寸る原因は，厚さが増すにしたがって初期亀裂とな る未溶着部が長くなり, 初期の応力拡大係数が大きくな るためと考えられる.

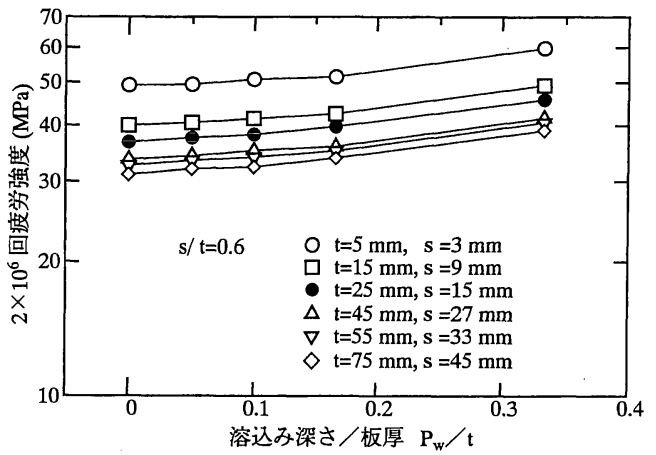

図ー9 疲労強度に及ぼす溶込み深さの影響

従来より顕著な板厚効果が生じることが確かめられて いる荷重非伝達型十字すみ肉継手・止端破壊などにおい ては, 疲労強度が板厚の 1 ／4乗に反比例して低下すると されており ${ }^{5)}$ ここで対象とした荷重伝達型十字すみ肉継 手・ルート破壊での結果と異なる. これは, 前者におい ては板厚効果が板厚による溶接止端での応力集中および 高い応力集中の生じる範囲の相違によって起こるのに対 し, 後者では前述のように板厚効果が初期亀裂長さの相 違によって生じる, すなわち板厚効果の生じるメカニズ ムが異なるためと考えられる。

\section{（2）溶接サイズの影響}

溶接サイズが疲労強度に及ぼす影響について検討した 結果を図ー8 (a)〜 ( $\mathrm{c}$ )に示す. 図の横軸は溶接サイズ $\mathrm{s} を$ 板厚 $\mathrm{t}$ で無次元化 $(\mathrm{s} / \mathrm{t})$ している. 図(a) では溶接形状 を二等辺三角形, 溶込みを 0 とし, 板厚を $5 \mathrm{~mm}$ から $75 \mathrm{~mm}$ まで変化させた場合の解析結果を示している.いずれ の板厚においても， $\mathrm{s} / \mathrm{t} か ゙ 0.5$ 以上の領域で疲労強度はほ ぼ一定となっているが, $\mathrm{s} / \mathrm{t}$ が 0.5 以下になると疲労強度 はs／tが減少するにしたがって高くなっている. 図(b)に 示すように溶接の溶込みがある場合，また図(c)に示すよ うに溶接形状を不等脚としても， $\mathrm{s} / \mathrm{t}>0.5$ で疲労強度は 一定となっており， $\mathrm{s} / \mathrm{t}$ が0.5以下になると $\mathrm{s} / \mathrm{t}$ 以゙小さく なるしたがって疲労強度は高くなっている.この傾向は, 他の溶接形状, 板厚, 溶込み樑さにおいても同じであっ た.

\section{（3）溶込み深さの影響}

図一 9 に $2 \times 10^{6}$ 回疲労強度と溶込み深さの関倸を示す. なお,この図では, $\Delta$ 形の溶接部を有する継手で, 溶接 サイズと板厚の比 $\mathrm{s} / \mathrm{t}$ が0. 6, 板厚が $5 \mathrm{~mm}$ 75mmの結果を示 している. 図の横軸は溶込み深さPwを板厚 $\mathrm{t}$ で無次元化 したものである.いずれの板厚においても，Pw／tが大き くなるにしたがって疲労強度が上昇している.この傾向 は他の溶接形状, 溶接サイズの継手においても同様で あった。したがって, 溶接の溶込みを深くすることは, のど断面積を大きくすること以上に疲労強度を上昇させ る効果があると言える. 


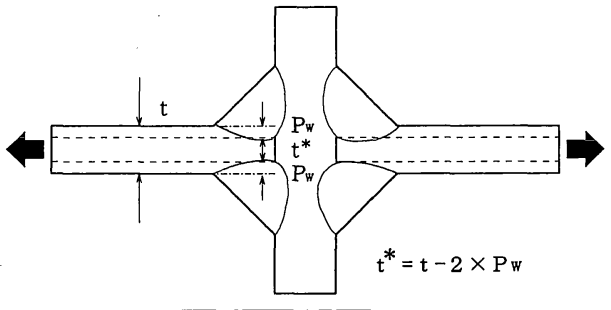

図-10 換算板厚の定義

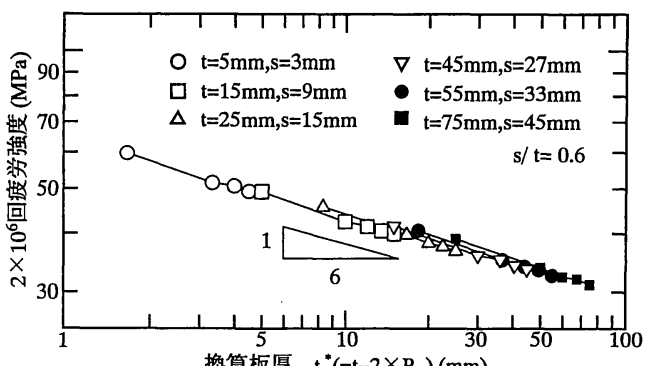

(a) $\Delta$ 形継手

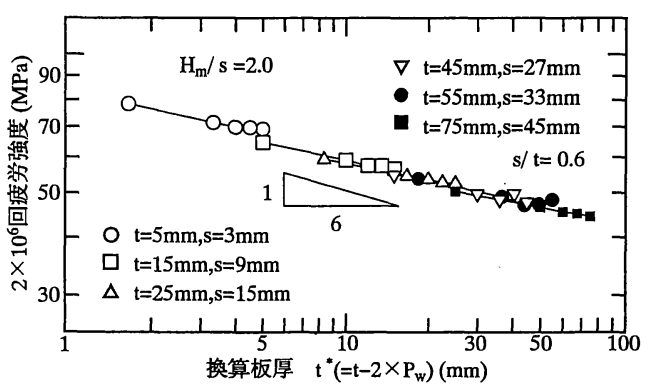

(b) $\triangle$ 形継手

図-11 $2 \times 10^{6}$ 回疲労強度と換算板厚の関係

このような溶接の溶込みによる疲労強度の上昇は、図一 10に示すように未溶着部が短くなり，応力の流れが滑ら かになるためと考えられる。この未溶着長さの減少を板 厚の減少としてとらえ，（板厚 $-2 \times$ 溶込み深さ）を換算 板厚 $\mathrm{t} *$ と定義し， $\mathrm{t} *$ で $2 \times 10^{6}$ 回疲労強度を整理した結果 を図一11(a)に示す．疲労強度は換算板厚 $\mathrm{t}^{*}$ のほぼ1/6乗 に反比例して直線的に減少している。これは，図一7に示 した疲労強度と板厚の関係と一致する. 図一11(b)は，主 板側に長い不等脚溶接継手での疲労強度と $\mathrm{t}$ *との関係 を示したものであるが，この場合も疲労強度は $t^{*}$ のほぼ 1／6乗に反比例して低下している. また，他の溶接形状, 溶接サイズについても同様な結果が得られた。

\section{（4）脚長比の影䈉}

不等脚なす夕肉溶接の脚長比を, は主板側の脚長 $\mathrm{Hm}$ 溶接サイズ $\mathrm{s}$ で除した值 $\mathrm{Hm} / \mathrm{s}$, $\Delta$ 形継手については $\mathrm{Hc} / \mathrm{s}$ ( $\mathrm{Hc}$ ：中板側の脚長）と定義す る.

図一12に $\Delta$ 形継手の $2 \times 10^{6}$ 回疲労強度と脚長比 $\mathrm{Hm} / \mathrm{s}$ の関倸を示す．この図では板厚 $25 \mathrm{~mm}$ で，溶接サイズを 5

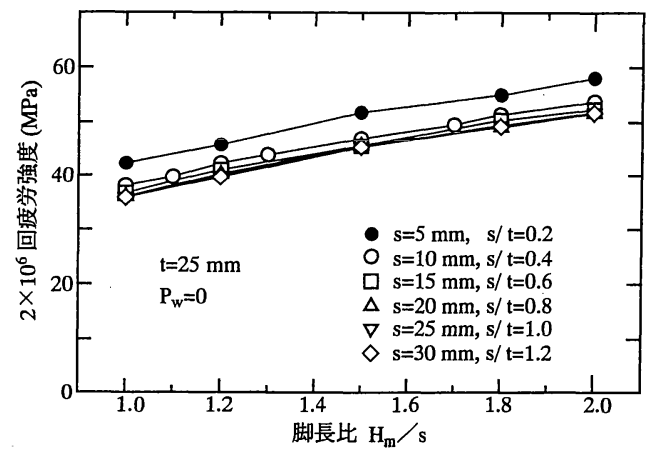

図-12 疲労強度に及ぼす脚長比の影響（

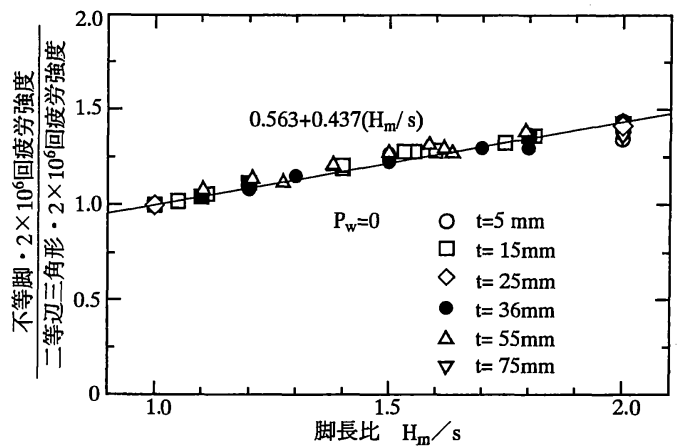

図 -13 無次元化疲労強度と脚長比の関係（ $\Delta$ 形継手）

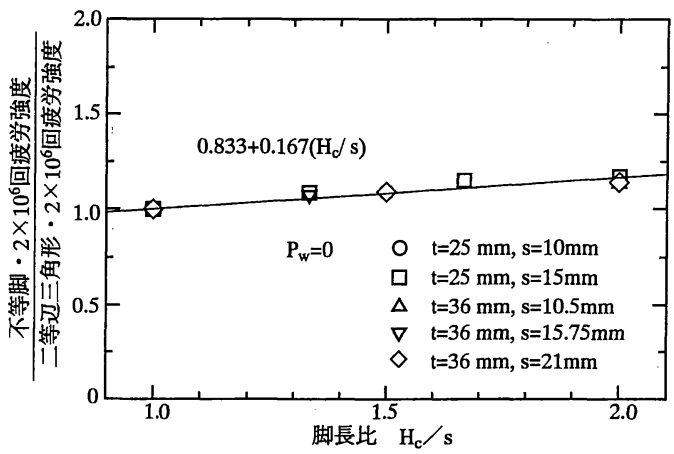

図-14 無次元化疲労強度と脚長比の関係（ $\Delta$ 形継手）

mm〜30mmまで変化させた場合の結果を示している. $\mathrm{Hm} / \mathrm{s}$ が 増すにしたがって，いずれの溶接サイズの継手においも 疲労強度はほぼ直線的に増加している，主板側に脚長を 大きくすることによる疲労強度の上昇の程度を明らかと するために, $\triangle$ 形継手の $2 \times 10^{6}$ 回疲労強度を同じ板厚 ・ 溶込み深さ・溶接サイズの $\Delta$ 形継手 $(\mathrm{Hm} / \mathrm{s}=1.0)$ の $2 \times$ $10^{6}$ 回疲労強度で無次元化した. その值と $\mathrm{Hm} / \mathrm{s}$ の関係を 図一13に示す. この無次元化疲労強度と脚長比の関係は, 次式で表すことができる.

$($ 無次元化疲労強度 $)=0.563+0.437(\mathrm{Hm} / \mathrm{s})$

$\Delta$ 形継手の無次元化疲労強度と脚長比 Hc $/ \mathrm{s}$ の関係を図 -14に示す. 疲労強度はHc／sが大きくなるにしたがっ 


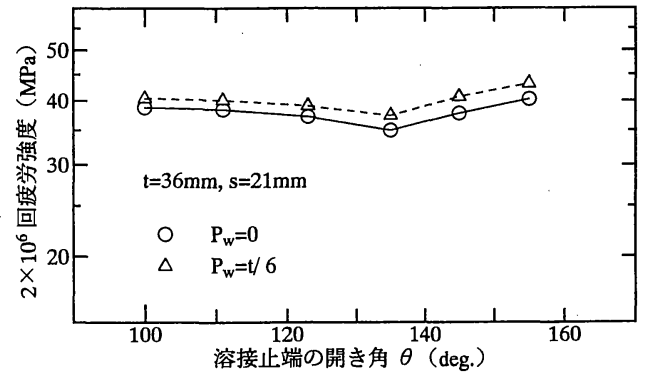

図-15 疲労強度に及ぼす溶接形状（凹凸）の影響

て高くなってるが，その程度はム形継手に比べて小さい． 無次元化疲労強度と $\mathrm{Hc} / \mathrm{s}$ の関係は, 次式で与えられる.

$($ 無次元化疲労強度 $)=0.833+0.167(\mathrm{Hc} / \mathrm{s})$

\section{（5）溶接形状の影響}

板厚 $36 \mathrm{~mm}$, 溶接サイズ $21 \mathrm{~mm}$ の形あるいは凸形の溶接形 状を有する継手の疲労強度と溶接止端の開き角 $\theta$ との関 係を図一15示す。なお，溶接形状は $\theta=135^{\circ}$ で二等辺三角 形, $\theta>135^{\circ}$ で凹形, $\theta<135^{\circ}$ で凸形となる. $\Delta$ 形継手 に比べて, 凹形あるいは凸形継手の疲労強度は高くなっ ている.このような疲労強度の上昇は, 凹形継手では $\Delta$ 形継手に比べて主板側の脚長が長くなること，凸形継手 では余盛りによってルート部への応力の流れが緩和され ることに原因があると考えられる。しかし，図一 15に示すように溶接形状による疲労強度の変化は小さい.

\section{6. 疲労強度評価方法の提案}

前章で, 板厚, 溶接サイズ, 溶込み深さ, 脚長比, 溶 接形状が疲労強度に及ぼす影響について検討した結果を 示した.これらの各因子による疲労強度の補正をのど断 面積を算定するためののど厚に換算すれば次式のように 表すことができる.

[(溶接サイズ十溶込み深さ) $/ \sqrt{2}] \times \alpha$

$$
\times[25 /\{\text { 板厚 }-2 \times(\text { 溶込み深さ })\}]^{1 / 6}
$$

$$
\begin{array}{ll}
\alpha=0.563+0.437(\mathrm{Hm} / \mathrm{s}) & (\mathrm{Hm} / \mathrm{s} \geqq 1.0) \\
\alpha=0.833+0.167(\mathrm{Hc} / \mathrm{s}) & (\mathrm{Hc} / \mathrm{s} \geqq 1.0)
\end{array}
$$

式(3)に基づき, 100 種類のモデルの $2 \times 10^{6}$ 回疲労強度 を等脚でフラットな形状のすみ肉溶接を有し，乙かも溶 込みのない板厚 $25 \mathrm{~mm}$ の継手の $2 \times 10^{6}$ 回疲労強度で無次 元化した結果を溶込み深さごとに図ー16(a)，(b)，(c)に 示す. 図中の記号は溶接サイズと板厚の比 $\mathrm{s} / \mathrm{t}$ で変え ているが， $\mathrm{s} / \mathrm{t} か ゙ 0.5$ 未満の継手では, 無次元化疲労強度 が 1 をかなり越えているものもある.これは, $\mathrm{s} / \mathrm{tが} 0.5$ 以下の領域ではs／tが小さくなるにしたがって疲労強度 が高くなるという効果を式(3)では考慮していないためで ある．溶接サイズの影響については，さらに検討す る必要もあると考えるが, 無次元化疲労強度が 1 を超

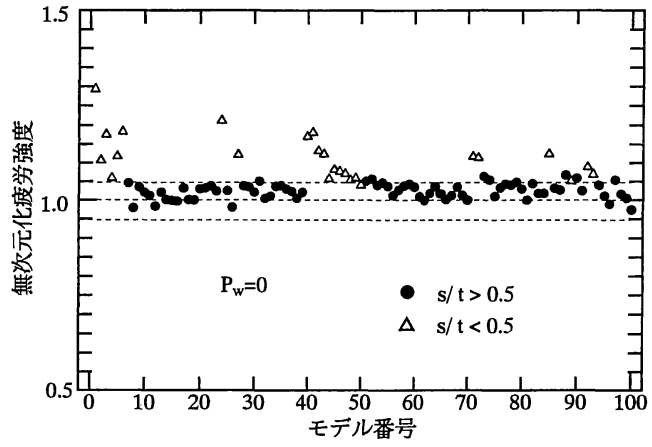

(a) 溶込み深さ $\mathrm{P}_{\mathrm{w}}=0$

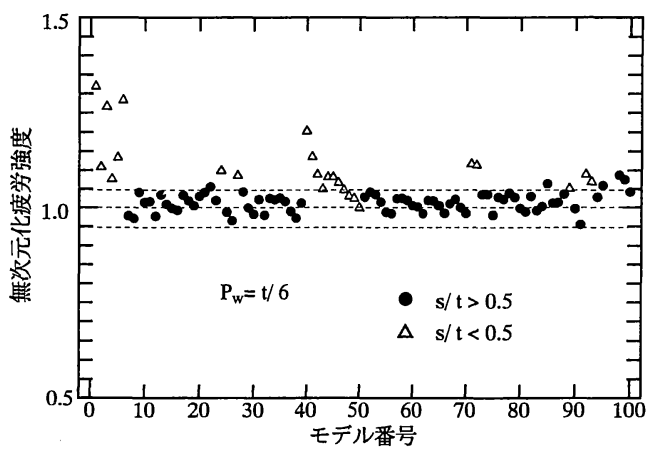

(b) 溶込み深さ $\mathrm{P}_{\mathrm{w}}=\mathrm{t} / 6$

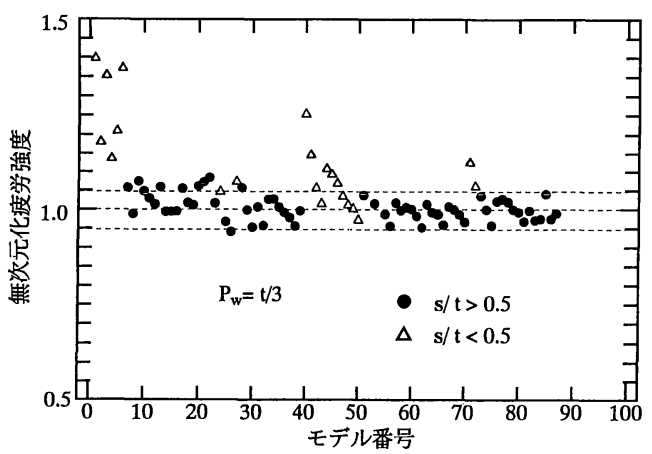

(c) 溶込み潹さ $P_{w}=t / 3$

图ー16 提案するのど厚算定法により評価した疲労強度

えるということは安全側の評価となることを意味してい る. 一方, $s / t か ゙ 0.5$ 以上継手では, いずれの溶込み深 さにおいても, 無次元化疲労強度がほぼ 0.95 から 1.05の範囲内にある。 したがって, 式(3)に従えば, 荷重 伝達型十字すみ肉溶接継手がルート破壊する場合の適切 な疲労強度評価が行なえると言える。

\section{7. まとめ}

本研究では, 種々の溶接形状を有する荷重伝達型十字 すみ肉溶接継手の疲労試験を行なうとともに, 種々の溶 接形状, 板厚, 溶接サイズ, 溶込み深さの継手を対象と した疲労亀裂進展解析を行ない, 荷重伝達型十字すみ肉 溶接継手の定量的な疲労強度評価方法について検討した. 
ここで得られた主な結果は以下の通りである.

（1）中板側に長い不等脚な溶接部を有する継手，凹形 および凸形の溶接部を有する継手の疲労強度は，同じ溶 接サイズの二等辺三角形の溶接部を有する継手と同程度 あるいは若干高い.これらに比べて, 主板側に長い不等 脚な溶接部を有する継手の疲労強度は高い。

（2）疲労強度は板厚のほぼ1／6乗に反比例して低下す る.

(3) (溶接サイズ / 板厚) $>0.5$ の領域では, 溶接サイズ によらず疲労強度は一定である. (溶接サイズ / 板厚 $<$ 0.5 の領域では，溶接サイズが小さくなるにしたがって疲 労強度は増加する.

（4）疲労強度は溶接の溶込みが深くなるにしたがって 高くなる．この効果は，溶接の溶込み深さだけ板厚が小 さくなると考え，（2）の結果を適用することにより評価 できる.

（5）定量的な疲労強度を行なうためののど厚の算定方 法を提案した.

[(溶接サイズ十溶込み深さ) $/ \sqrt{2}] \times \alpha$

$$
\begin{aligned}
& \times[25 /\{\text { 板厚 }-2 \times(\text { 溶込み深さ })\}]^{1 / 6} \\
& \alpha=0.563+0.437(\mathrm{Hm} / \mathrm{s}) \quad(\mathrm{Hm} / \mathrm{s} \geqq 1.0) \\
& \alpha=0.833+0.167(\mathrm{Hc} / \mathrm{s}) \quad(\mathrm{Hc} / \mathrm{s} \geqq 1.0)
\end{aligned}
$$

謝 辞：試験体製作に際しては田中雅人氏（東京鉄骨橋梁） に多大なる御協力を賜った．ここに記して，梁く感謝する. また, 本研究は文部省科学研究費補助金・総合研究 (A) (代表 藤野陽三）の一部として行なったことを付記する.

参 考 文 献

1) 三木千壽・坂野昌弘・館石和雄・福岡良典：鋼橋の疲労損 傷事例のデータベースの構築とその分析, 土木学会論文集, No. 392/ I -9, pp. 403 410, 1988.

2) Frank,K.H. and Fisher,J.W. : Fatigue Strength of Fillet Welded Cruciform Joints, Proceed-ings of ASCE, ST9, 1727 1740, 1979.

3 ）館石和雄 - 三木干壽・森猛 : 隅肉溶接継手部のせん断応力 設計疲労曲線の検討, 東工大土木工学科研究報告, No. 42 , pp. 1 9, 1990.

4）森猛・貝沼重信 -三木千壽 : 荷重伝達型十字すみ肉溶接継 手ルート破壊の疲労強度解析, 構造工学論文集, Vol. 39A, pp. $937 \sim 946,1993$.

5 ）日本鋼構造協会：疲労設計指針(案), JSSCレポート, No. 14, 1989.

6 ）日本鋼構造協会 : 鋼構造物の疲労設計指針・同解説, 技報堂出版, 1993 .

7 ）曽根貢・関貴志・森猛 : 荷重伝達型十字すみ肉溶接継手の 疲労破壊起点の検討, 土木学会第19回関東支部技術研究発 表会講演概要集, I-31, 1992.

8）貝沼重信・森猛・川嶋克昌：荷重伝達型十字寸み肉溶接継 手のルート部から発生する疲労亀裂の進展性状, 土木学会 第47回年次学術講演会講演概要集, I-125, 1992.

(1994.3.28 受付)

\section{FATIGUE STRENGTH EVALUATION METHOD FOR LOAD-CARRYING FILLET WELDED CRUCIFORM JOINTS}

Takeshi MORI and Shigenobu KAINUMA

In order to make clear the fatigue strength evaluation method for load-carrying fillet welded joints failing from weld roots, fatigue tests on the joints with fillet welds of various shapes (isosceles triangle, two types of scalene triangle, concave, convex) have been carried out. Fatigue crack propagation analyses have been also performed for the tested joints and one hundred models of the joint. On the basis of experimental and analytical results, the influence of weld shape, weld size, weld penetration and plate thickness on the fatigue strength are made clear, and then, a numerical expression of weld throat is proposed for evaluating the fatigue strength. 